\title{
Comparative investigation of Sididae (Crustacea: Branchiopoda: Cladocera) of Northern and Western Thailand, with additional notes on Diaphanosoma senegal isanensis Korovchinsky et Sanoamuang, 2008
}

\section{Сравнительное исследование Sididae (Crustacea: Branchiopoda: Cladocera) Северного и Западного Таиланда с дополнительными замечаниями о Diaphanosoma senegal isanensis Korovchinsky et Sanoamuang, 2008}

\author{
N.M. Korovchinsky ${ }^{1}$, La-orsri Sanoamuang ${ }^{2}$ \\ Н.M. Коровчинский ${ }^{1}, \Lambda .-о$. Саноамуанг $^{2}$
}

\footnotetext{
${ }^{1}$ A.N. Severtsov Institute of Ecology and Evolution, Leninsky prospect 33, Moscow 119071, Russian Federation. E-mail: nmkor@yandex.ru ${ }^{1}$ Институт проблем экологии и эволюции им. А.Н. Северцова РАН, Ленинский проспект, 33, Москва 119071, Российская Федерация.

2 Applied Taxonomic Research Center, Faculty of Sciences, Khon Kaen University, Khon Kaen 40002 and Faculty of Sciences, Mahasarakham University, 44150 Maha Sarakham, Thailand. E-mail: la_orsri@kku.ac.th

${ }^{2}$ Центр прикладных таксономических исследований, Факультет наук, Университет Кхон Кен, Кхон Кен 40002 и Факультет наук, Университет Махасаракхам, 44150, Маха Саракхам, Таиланд.
}

KEY WORDS: Cladocera, Sididae, Northern and Western Thailand, Diaphanosoma senegal isanensis.

КЛЮЧЕВЫЕ СЛОВА: Cladocera, Sididae, Северный и Западный Таиланд, Diaphanosoma senegal isanensis.

ABSTRACT. The first extensive investigation of Cladocera from Northern and Western Thailand has revealed eight species of the family Sididae (Diaphanosoma excisum Sars, 1885, D. dubium Manuilova, 1964, D. sarsi Richard, 1894, D. volzi Stingelin, 1905, D. senegal isanensis Korovchinsky et Sanoamuang, 2008, D. elongatum Korovchinsky et Sanoamuang, 2008, Latonopsis australis Sars, 1888, Pseudosida szalayi (Daday, 1898)) among which two former species, Diaphanosoma excisum and D. dubium, were most widely distributed and abundant; while, D. senegal isanensis and D. elongatum were rare or extremely rare, found only in four and one locality, respectively. Sididae species were often observed co-occurring in different combinations, among them up to three species of Diaphanosoma have been recorded as sympathric. A few species of the Sididae of northern origin found earlier in Northeastern Thailand were not encountered in the regions under consideration, probably due to their comparatively higher elevation and isolation from the influence of large rivers flowing from the north and promoting the migration of aquatic species to the south. Additional investigation of $D$. senegal isanensis, including its representatives from Laos and Cambodia, has allowed to analyze size-frequency distribution and age-dependent morphological variability, to describe males of the subspecies for the first time and to summarize data of subspecies distribution throughout Southeast Asia.
РЕЗЮМЕ. Первое обширное исследование Cladocera из Северного и Западного Таиланда выявило восемь видов семейства Sididae (Diaphanosoma excisum Sars, 1885, D. dubium Manuilova, 1964, D. sarsi Richard, 1894, D. volzi Stingelin, 1905, D. senegal isanensis Korovchinsky et Sanoamuang, 2008, D. elongatum Korovchinsky et Sanoamuang, 2008, Latonopsis australis Sars, 1888, Pseudosida szalayi (Daday, 1898)), из которых два первых вида наиболее широко распространены и обильны, тогда как D. senegal isanensis и $D$. elongatum оказались редким или исключительно редким видом, будучи найдены, соответственно, в четырёх и одном местонахождении. Виды Sididae сосуществовали в различных комбинациях, среди них были найдены до трёх видов рода Diaphanosoma, живущих вместе. Немногие виды Sididae северного происхождения, найденные прежде в Северо-Восточном Таиланде, не были обнаружены в районах исследования, вероятно, вследствие их большей высоты над уровнем моря и изоляции от влияния крупных рек, текущих с севера и способствующих миграции водных организмов в южном направлении. Дополнительное исследование $D$. senegal isanensis, включая представителей из Лаоса и Камбоджи, позволило проанализировать размерно-возрастное распределение и возрастную морфологическую изменчивость, сделать первое описание самцов подвида и суммировать данные по его распространению в Юго-Восточной Азии. 


\section{Introduction}

During recent decades, the taxonomic diversity of Thai Cladocera has intensively been investigated, but mostly in the northeastern region [Sanoamuang, 1998; Saeng-aroon and Sanoamuang, 2002; Sanoamuang, Faitakum, 2005; Korovchinsky, Sanoamuang, 2008a] and southern region [Sa-ardrit, 2002; Maiphae et al., 2005, 2008] of the country while the other regions were surveyed insufficiently. There is a single publication on Cladocera from one stream in Western Thailand with 40 species recorded [Sa-ardrit and Beamish, 2005]. In Northern Thailand, samples with Cladocera were collected only in two [Kotov and Sanoamuang, 2004] and then nine localities [see Maiphae et al., 2008], but results of the latter investigation were not specified. Thus, these two regions of Thailand remained practically unexplored with respect of this important freshwater crustacean group.

The investigation of numerous samples stored in the collection of the Applied Research Taxonomic Center of Khon Kaen University made it possible to evaluate the frequency of the occurrence of different cladoceran groups inhabiting water bodies in Northern and Western Thailand, with special attention to representatives of the family Sididae which often plays the primary role in local aquatic communities. Investigation of some additional samples from adjacent countries, Laos and Cambodia, yielded more data on the rare species Diaphanosoma senegal isanensis in Southeast Asia.

\section{Study area, material and methods}

Thailand is a tropical country in South-East Asia with a monsoonal climatic regime. Based on natural features, including landforms and drainage, Thailand is divided into six geographical regions: northern, northeastern, central, eastern, western and southern regions. The northern and western regions (Fig. 1) of the country are characterized by the presence of high mountains (average elevation about $1500 \mathrm{~m}$ a.s.l.) and consequently a more seasonal climate, the latter region hosts much of Thailand's less-disturbed forest areas.

Samples for this investigation were provided from the personal collection of La-orsri Sanoamuang at the Applied Taxonomic Research Center of Khon Kaen University (Khon Kaen, Thailand). They were collected in 2000-2002 and 2007, and studied in November 2010.The selected specimens were analyzed further at the Institute of Ecology and Evolution (Moscow, Russia). In total, 475 samples were investigated, 354 of which contained cladocerans. Most of them (308) were collected from Northern Thailand and fewer samples (46) from the western provinces of the country (Fig. 1) in water bodies of different types: lakes, reservoirs, ponds, temporary ponds, swamps, canals and rice fields. The majority of the samples from Northern Thailand were collected seasonally, three times per locality, but due to frequent difference in species composition all of them were regarded as being collected from different localities. To present, the label data for many samples and data on environmental variables of the sampling sites have not been kept in full and this circumstance prevented a more detailed analysis.

Samples were examined under the dissecting microscopes Olympus SZX9 and Lomo-10 with a special Bogorov chamber for zooplankton quantitative investigation; selected specimens were then studied under a compound microscope, Olympus BX41, with a camera lucida and a photo camera Infinity 1.

The central focus was on the family Sididae, the representatives of which were studied in detail, while other cladocerans were identified mostly to generic or family level and large branchiopods only to the order level.

The rare subspecies of Sididae, Diaphanosoma senegal isanensis was found in the following four localities in Northern Thailand: 1) unknown water body, Phitsanulok Prov., 11.08.2000, 4 ad, 2 juv, 2) sample 118, pond in rice field, Srisatchanalai dt., Sukhothai Prov., 11.08.2000, 6 ad, 1 juv, 3) sample 198, unknown locality and date, 2 ad, 4) sample 327, road-side canal, Kamphaengphet Prov., 12.04.2002, 404 ad and juv, 2 gam, and 21 males. Additionally this subspecies was encountered in two samples from Laos (Champasak Prov., Pathoumphone dt., 16.11. 2005 and 17.11.2005, 5 ad, 8 juv and 54 ad, 18 juv, 2 males, respectively) and in two samples from Cambodia (Kandal Prov., 16.06.2006, turbid pond, 28 ad, 12 juv; Kampong Cham Prov., turbid pond, 18.10.2006, 9 ad, 1 juv).

D. elongatum Korovchinsky et Sanoamuang, 2008 was found in a sample from the Pasak Cholasit Dam (Lopburi Prov., 5.08. 2000, 1 ad, deformed).

Abbreviations: ad - adult parthenogenetic female, gam - gamogenetic female, juv - juvenile parthenogenetic female.

\section{Results}

\section{Sididae and other Branchiopoda}

Members of the family Sididae were found in 277 localities (78\% of localities with Cladocera) while other Branchiopoda groups were found more infrequently (Fig. 2). Among the latter, Daphniidae, Moinidae, and Chydoridae appeared to be most common, represented in 36,42 , and $34 \%$ of the localities, respectively, while others were more sporadic and less numerous. Among large Branchiopoda, only the representatives of $\mathrm{Cy}-$ clestherida were found comparatively frequently (in $7 \%$ of localities) but other members of the group seemed very rare.

Among Daphniidae, Ceriodaphnia was most common (in 28\% of localities), whereas Simocephalus and Scapholeberis were much less common (in $8 \%$ and $4 \%$ of localities), and Daphnia lumholtzi Sars might be regarded as rare species $(0.6 \%)$ (Fig. 3). Within the Moinidae, Moina species were much more frequently 


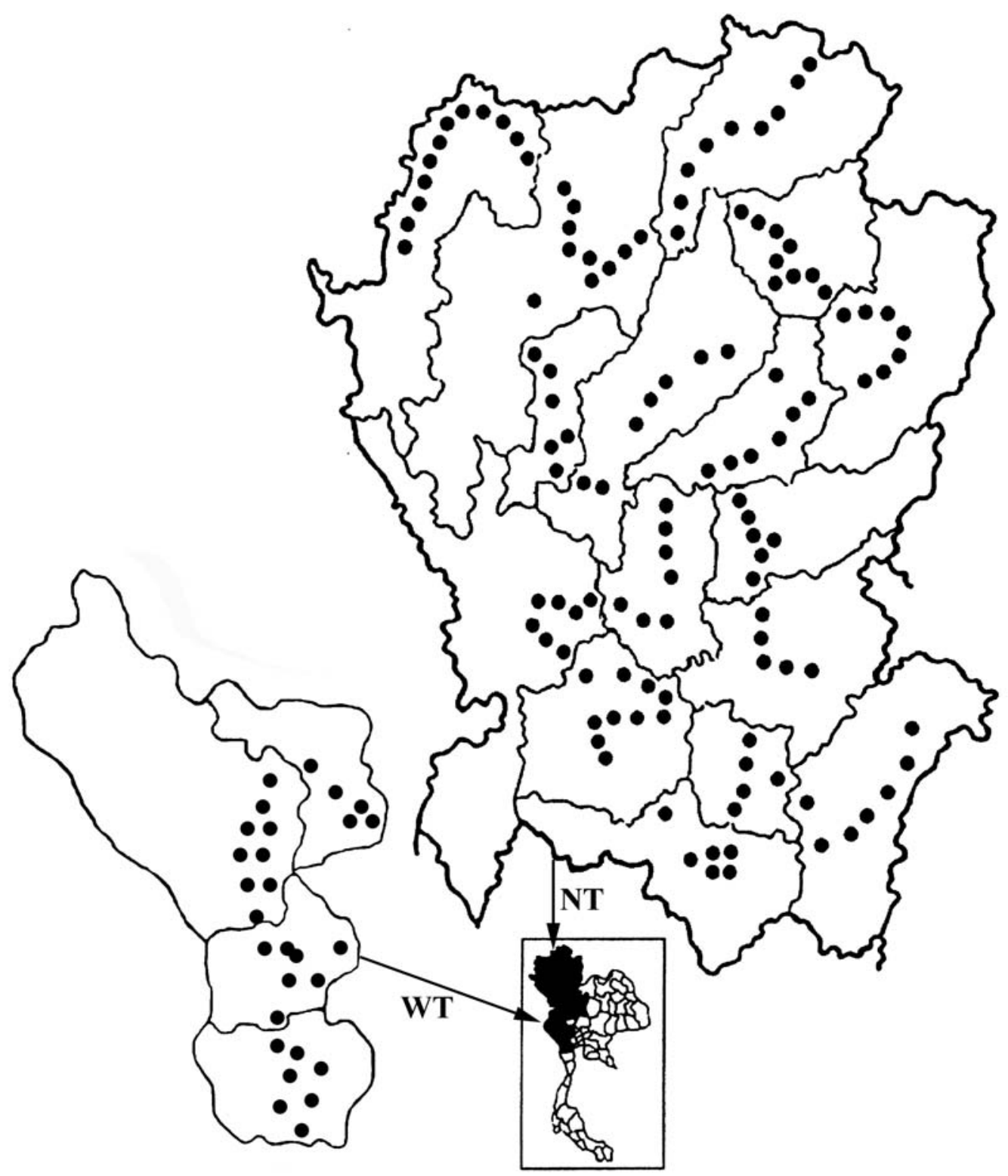

Fig. 1. Regions of Northern (NT) and Western (WT) Thailand where samples were collected.

Рис. 1. Регионы Северного (NT) и Западного (WT) Таиланда, где были собраны исследованные пробы.

encountered (in $35 \%$ of localities) than those of Moinodaphnia (4\%). In Bosminidae, Bosminopsis was much more common (in $14 \%$ of localities) than rare representatives of Bosmina (1\%).

Species richness and frequency distribution of Sididae

In total, eight species of the family were found (Fig. 4), among which members of the genus Diaphanosoma were most numerous, being represented by six species. Only two of these species were common, D. excisum Sars (in $69 \%$ of localities) followed by $D$. dubium Manuilova (in 23\% of localities). All other diaphanosomas may be regarded as rare or very rare, for exam- ple, D. senegal Gauthier (1\%) and D. elongatum. The latter species was found only in a single locality in Northern Thailand, being represented by only one deformed female with a body length of $0.70 \mathrm{~mm}$. $D$. senegal was represented by recently described subspecies D. senegal isanensis [see Korovchinsky and Sanoamuang, 2008b] found in four localities in Northern Thailand.

Two other genera, Latonopsis and Pseudosida, were represented by only a single species each, namely $L$. australis Sars and P. szalayi (Daday). The latter species is now known as the only species of the genus in southern Asia [Korovchinsky, Sanoamuang, 2008a; Korovchinsky, 2010]. Both species, especially the former 


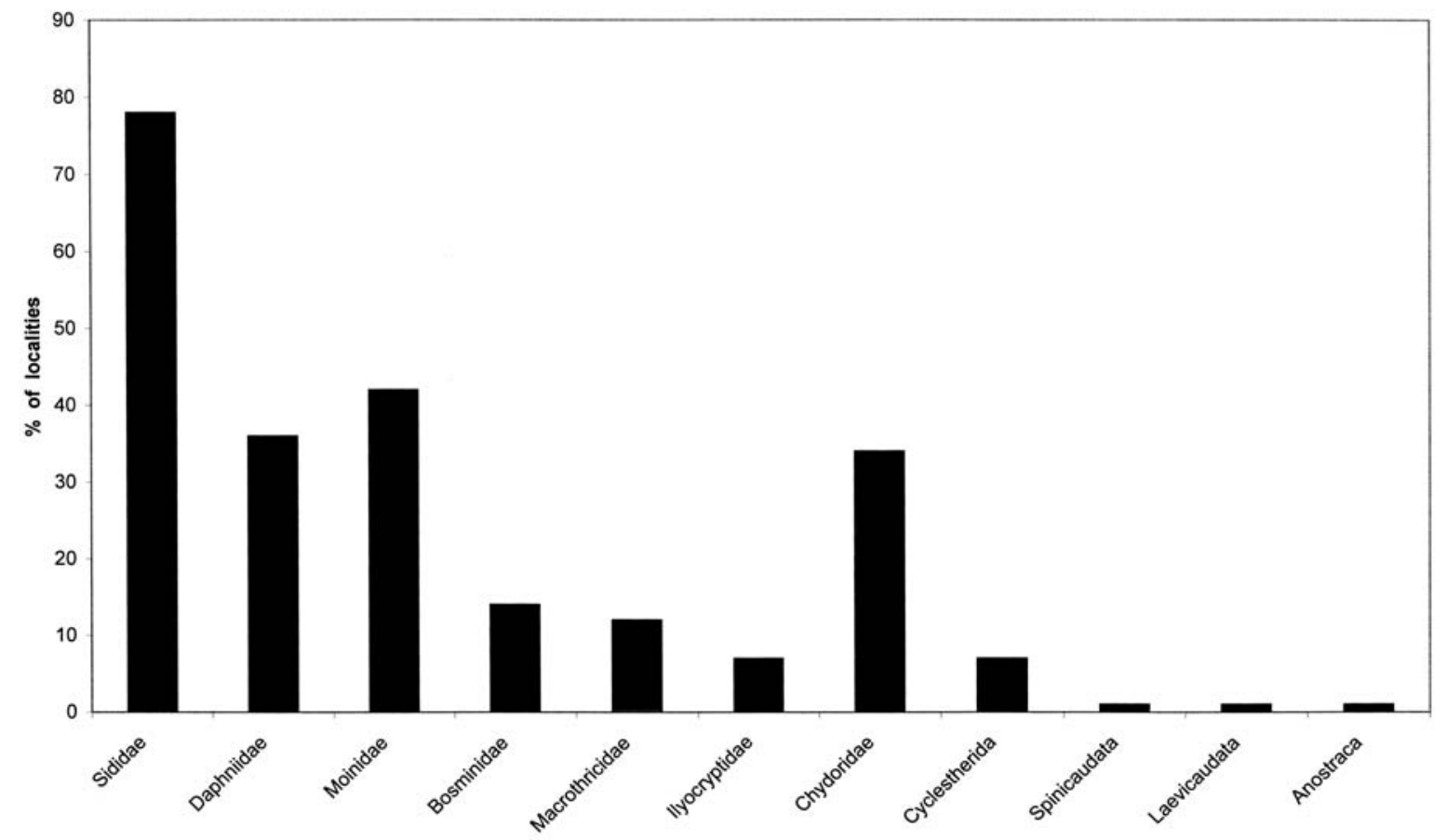

Fig. 2. Frequency of occurrence of representatives of different Branchiopoda groups. Рис. 2. Частота встречаемости представителей разных групп Branchiopoda.

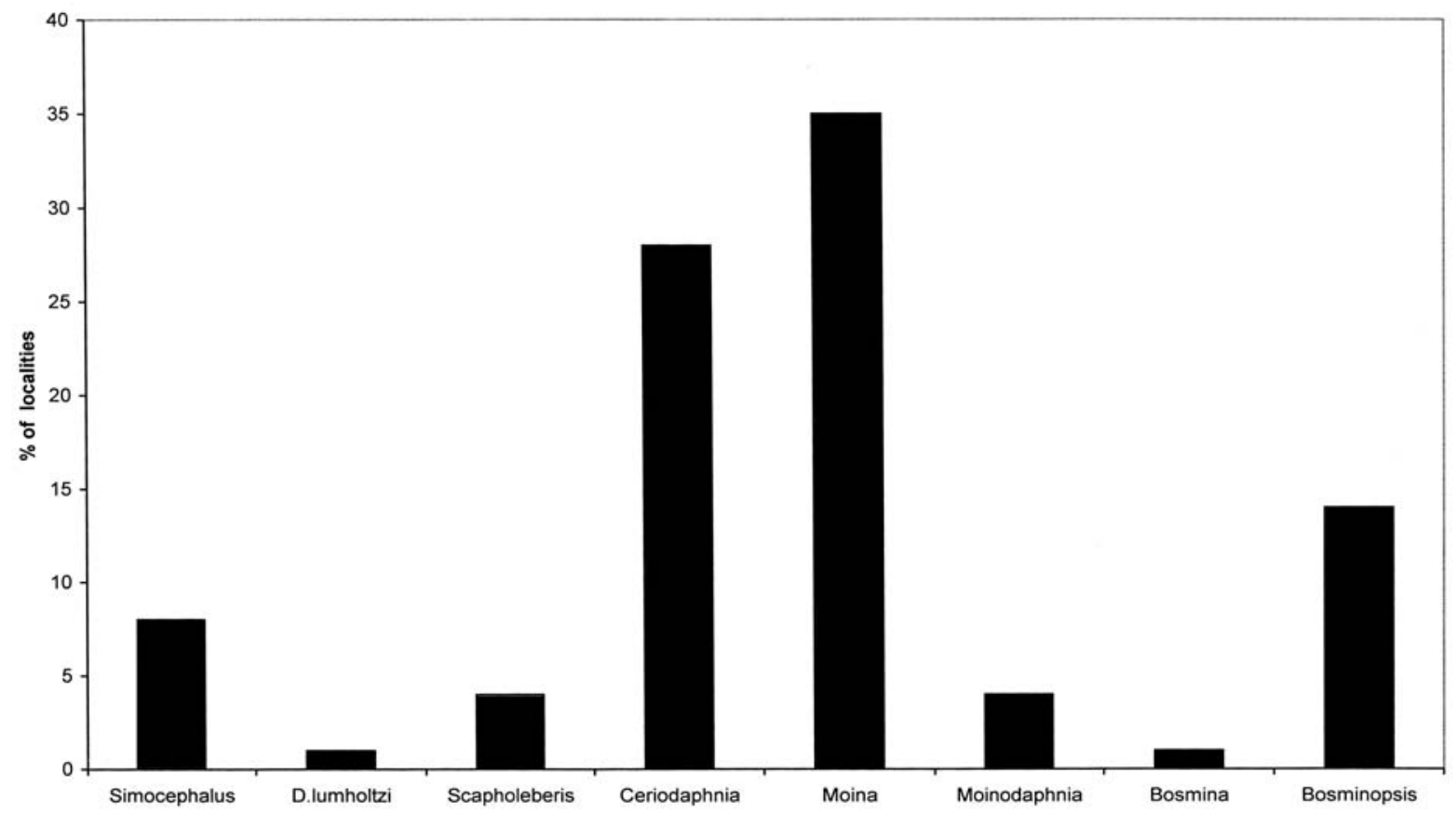

Fig. 3. Frequency of occurrence of representatives of Daphniidae, Moinidae and Bosminidae.

Рис. 3. Частота встречаемости представителей семейств Daphniidae, Moinidae и Bosminidae. 


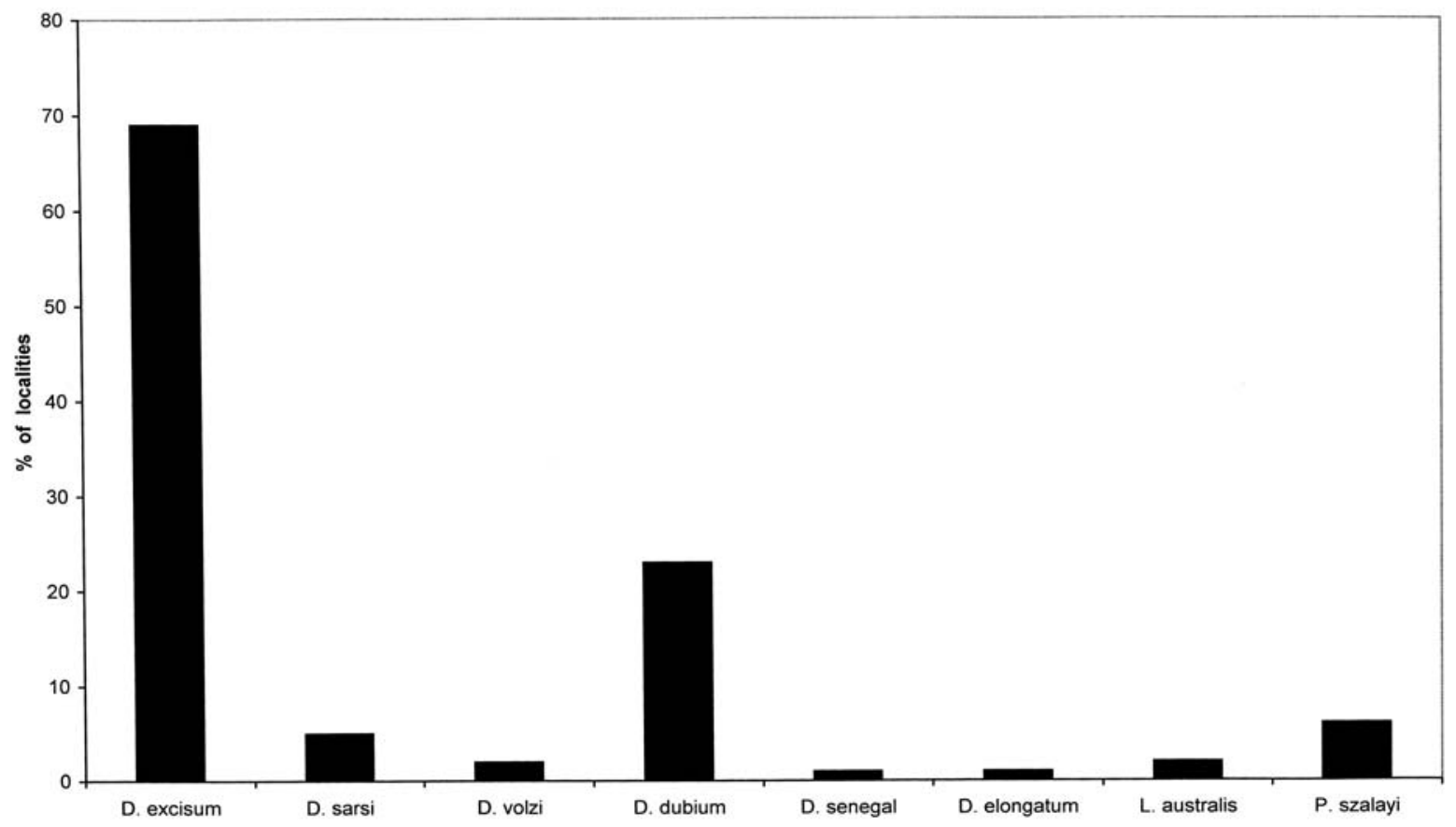

Fig. 4. Frequency of occurrence of Sididae species.

Рис. 4. Частота встречаемости видов семейства Sididae.

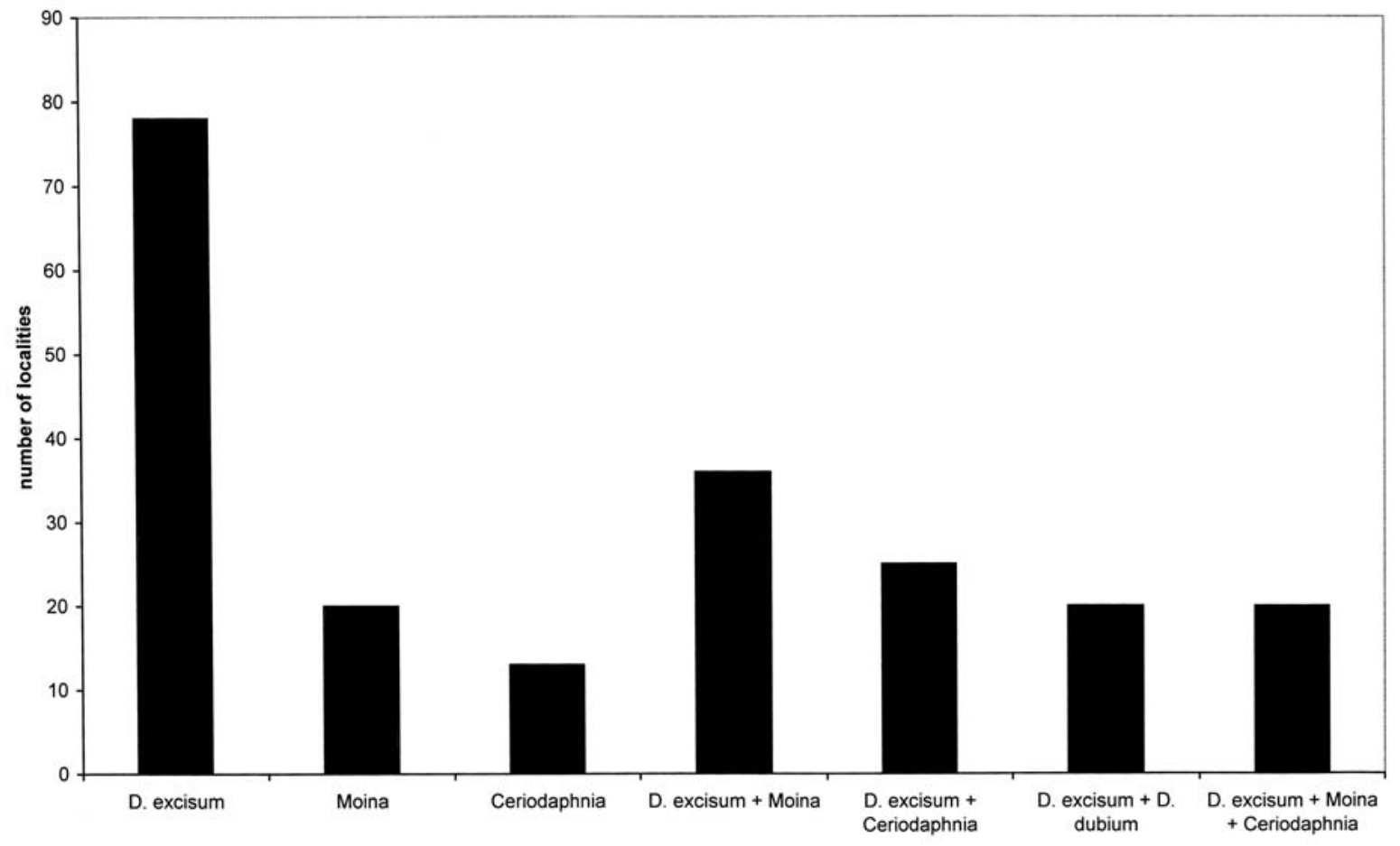

Fig. 5. Frequency of occurrence of most characteristic planktonic cladoceran assemblages.

Рис. 5. Частота встречаемости наиболее характерных планктонных группировок кладоцер. 


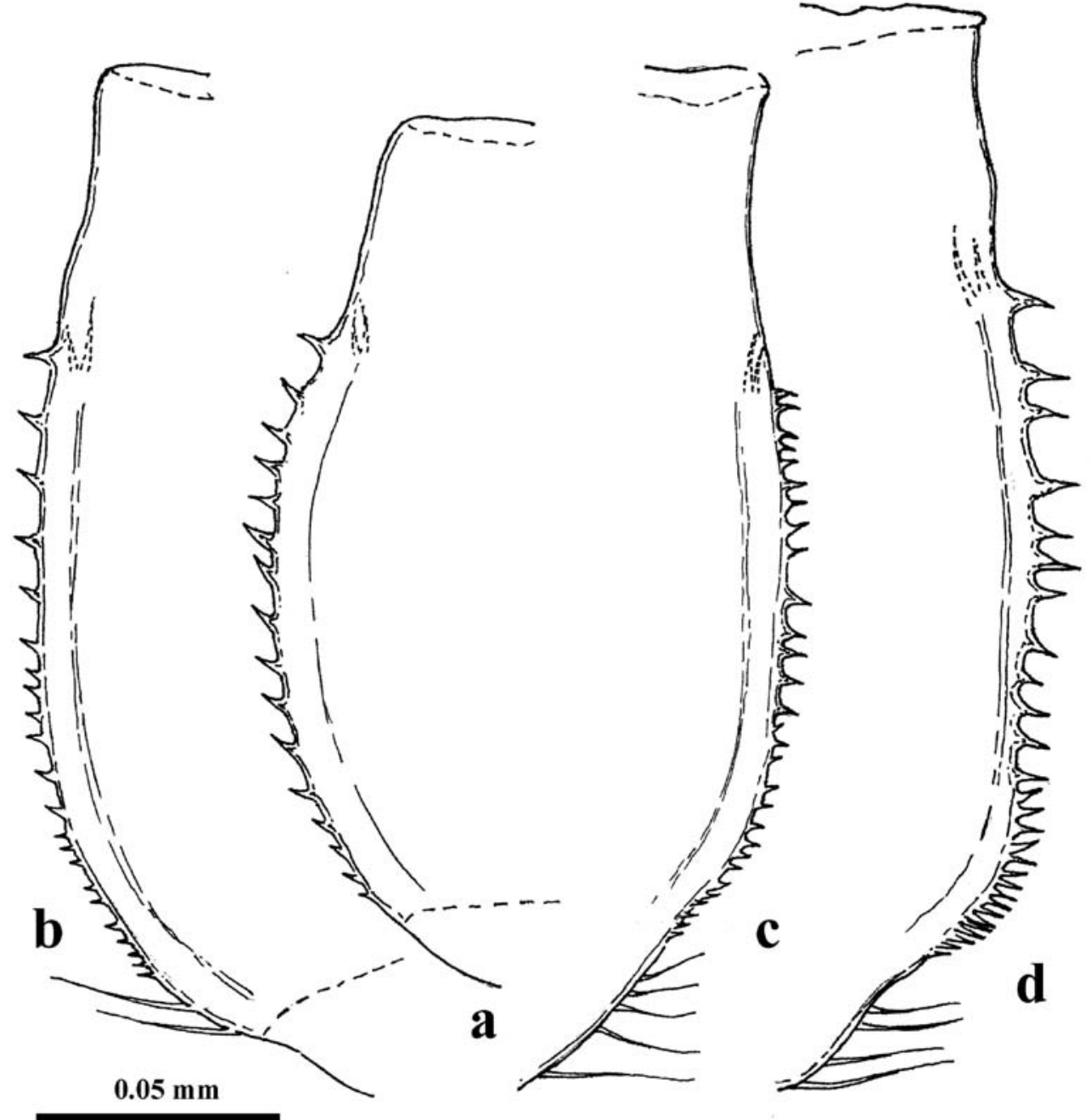

Fig. 6. Armament of posterior valve margins of Diaphanosoma senegal isanensis specimens of different ages and sizes $(\mathrm{a}-0.53 \mathrm{~mm}$, $\mathrm{b}-0.62 \mathrm{~mm}, \mathrm{c}-0.69 \mathrm{~mm}, \mathrm{~d}-0.75 \mathrm{~mm}$ ) (sample 327).

Рис. 6. Вооружение заднего края створок особей Diaphanosoma senegal isanensis разного возраста и размера (а - 0,53 мм, $\mathrm{b}-0,62$ мм, с - 0,69 мм, d-0,75 мм) (проба 327).

one, were comparatively rare (in $2 \%$ and $6 \%$ of localities, respectively).

Most cladoceran populations were represented exclusively by parthenogenetic females. Gamogenetic individuals (females and males) were found only in three populations of $D$. excisum, all collected in August in a roadside pond, river and reservoir in Northern Thailand, and in two populations of $D$. senegal isanensis from Northern Thailand (N 327) and Laos collected in April and November.

\section{Cladoceran planktonic assemblages}

The planktonic cladocerans of the genera Diaphanosoma, Moina, Ceriodaphnia, Daphnia, Bosminopsis and Bosmina were encountered in all possible combinations; the most common of them are represented in Fig. 5. Among them, D. excisum was often found as the only planktonic species of the group (in 78 localities) followed by Moina and Ceriodaphnia (in 20 and 13 localities respectively). Among others, combinations of the two-three most common taxa were frequently recorded (in 20-36 localities each) (Fig. 5). Combinations of four-five planktonic taxa were also comparatively common while the assemblages of six taxa $(D$. excisum, D. dubium, D. sarsi, Ceriodaphnia, Bosminopsis, Moina (or Bosmina instead)) were found twice, and seven taxa (D. excisum, D. dubium, D. elongatum, Daphnia lumholtzi, Moina, Ceriodaphnia, Bosminopsis) were found only once.

\section{Co-occurrence of Sididae species}

Monospecific occurrences of Sididae species were observed in about half of the localities (179), most of them (155) were represented by D. excisum (Table 1). Other sidids, including rare species (D. volzi Stingelin, $D$. senegal isanensis, L. australis), were rarely found 
Table 1. Matrix of pairwise co-ocurrence of Sididae species (cells with the numbers of monospecific occurrences are in bold). Таблица 1. Матрица случаев парного сосуществования видов Sididae (ячейки, указывающие на присутствие одного вида, отмечены жирным шрифтом).

\begin{tabular}{|l|c|c|c|c|c|c|c|}
\hline & D. excisum & D. sarsi & D. dubium & D. volzi & D. senegal & L. australis & P. szalayi \\
\hline D. excisum & $\mathbf{1 5 5}$ & 13 & 62 & 3 & 3 & 2 & 13 \\
\hline D. sarsi & 13 & $\mathbf{3}$ & 6 & 4 & 0 & 0 & 2 \\
\hline D. dubium & 62 & 6 & $\mathbf{1 3}$ & 1 & 0 & 2 & 1 \\
\hline D. volzi & 3 & 4 & 1 & $\mathbf{1}$ & 0 & 0 & 2 \\
\hline D. senegal & 3 & 0 & 0 & 0 & $\mathbf{1}$ & 0 & 1 \\
\hline L. australis & 2 & 0 & 2 & 0 & 0 & $\mathbf{2}$ & 2 \\
\hline P. szalayi & 13 & 2 & 1 & 2 & 1 & 2 & 4 \\
\hline
\end{tabular}

Table 2. Co-occurrences of three to four species of Sididae. Таблица 2. Случаи сосуществования трёх - четырёх видов Sididae

\begin{tabular}{|c|c|c|c|c|c|c|c|c|c|}
\hline $\begin{array}{c}D . \\
\text { excisum }\end{array}$ & $\begin{array}{c}D . \\
\text { sarsi }\end{array}$ & $\begin{array}{c}D . \\
\text { dubium }\end{array}$ & $\begin{array}{c}\text { D. } \\
\text { volzi }\end{array}$ & $\begin{array}{c}\text { D. elon- } \\
\text { gatum }\end{array}$ & $\begin{array}{c}D . \\
\text { senegal }\end{array}$ & $\begin{array}{c}\text { L. } \\
\text { australis }\end{array}$ & $\begin{array}{c}P . \\
\text { szalayi }\end{array}$ & $\begin{array}{c}\text { Number of } \\
\text { species }\end{array}$ & $\begin{array}{c}\text { Number of } \\
\text { localities }\end{array}$ \\
\hline $\mathrm{XXXX}$ & & $\mathrm{XXXX}$ & & & & $\mathrm{XXXX}$ & & 3 & 1 \\
\hline $\mathrm{XXXX}$ & & & & & $\mathrm{XXXX}$ & & $\mathrm{XXXX}$ & 3 & 1 \\
\hline $\mathrm{XXXX}$ & $\mathrm{XXXX}$ & $\mathrm{XXXX}$ & & & & & & 3 & 4 \\
\hline $\mathrm{XXXX}$ & & $\mathrm{XXXX}$ & & $\mathrm{XXXX}$ & & & & 3 & 1 \\
\hline $\mathrm{XXXX}$ & $\mathrm{XXXX}$ & & $\mathrm{XXXX}$ & & & & & 3 & 2 \\
\hline & $\mathrm{XXXX}$ & $\mathrm{XXXX}$ & $\mathrm{XXXX}$ & & & & $\mathrm{XXXX}$ & 4 & 1 \\
\hline $\mathrm{XXXX}$ & $\mathrm{XXXX}$ & & $\mathrm{XXXX}$ & & & & $\mathrm{XXXX}$ & 4 & 1 \\
\hline $\mathrm{XXXX}$ & & $\mathrm{XXXX}$ & & & & $\mathrm{XXXX}$ & $\mathrm{XXXX}$ & 4 & 1 \\
\hline
\end{tabular}

in such an occurrence. Also, D. elongatum (not included in Table 2), was found in one sample with $D$. excisum and $D$. dubium. It becomes clear from the table that the latter two most common species co-occurred especially often.

In most cases, two species of Sididae co-occurred, but in 12 localities a variety of combinations of three and four species were encountered (Table 2). Again, the most common species mentioned above were prominent. Species of Diaphanosoma formed three-species assemblages in nine localities, in four of them $D$. excisum together with $D$. dubium and D. sarsi Richard were present. In Northern Thailand, the rare D. senegal isanensis was found together with Anostraca only in a single locality while in Cambodia, such a co-occurrence was observed in two localities.

\section{Notes on Diaphanosoma senegal isanensis}

Data on morphological variability of adult females of this subspecies collected in Northern Thailand, Laos and Cambodia mostly coincide with that described earlier [see Korovchinsky \& Sanoamuang, 2008b]. At the same time, their posterior valve margin was observed as sometimes having more numerous upper large denticles (up to 25) while the lower small ones number only $3-10$ or might be absent completely. In one female from Laos, one valve bore three inner small spine-like, finely plumose setae near the posterior margin instead of the usual two setae. Lateral sides of postabdomen bore 3-8 anal denticles, i.e., slightly more than it was recorded before. The maximum body length in the studied females is $1.62 \mathrm{~mm}$.

A large amount of specimens of $D$. senegal isanensis found in one locality (Northern Thailand, sample N
327) allowed the investigation of age-dependent morphological variability and size-frequency distribution. In particular, the armament of the posterior valve margin is transformed with age from a more simple pattern in smallest individuals (marginal denticles are small and more uniform, lower emargination with setae is absent) (Fig. 6a), similar to that of other diaphanosoms, to a more complicated one in pre-adult and adult individuals (Fig. 6b-d). This probably implies secondary evolutionary transformation of the posterior valve margin of the species. Also the smallest individuals with body length $0.50-0.69 \mathrm{~mm}$ had only 3 and 7 setae on the proximal and distal segments of the upper antennal branch.

The size-frequency distribution of specimens from the aforementioned locality is shown in Fig. 7. Most individuals were represented by both immature and mature parthenogenetic females in more or less equal proportions. Minimum size of juveniles was $0.50 \mathrm{~mm}$ and that of egg-bearing female - $1.06 \mathrm{~mm}$, which is slightly larger than it was recorded previously (see Korovchinsky \& Sanoamuang, 2008b: $0.99 \mathrm{~mm}$ ). The biggest parthenogenetic female had a body length of $1.60 \mathrm{~mm}$. Most of these females had 1-2 eggs of ovalelongated shape $(0.26-0.27 \times 0.10-0.11 \mathrm{~mm})$ in their brood pouches. Two gamogenetic females had body lengths 1.23 and $1.25 \mathrm{~mm}$ and each bore two dark resting eggs of oval flattened shape $(0.21 \times 0.16 \times 0.11$ $\mathrm{mm}$ ) with a rough surface in their brood pouches (Fig. $8 \mathrm{~g})$. Juvenile males had body length between $0.62-$ $0.75 \mathrm{~mm}$, undeveloped antennules and copulatory appendages, in larger adult individuals $(0.75-0.91 \mathrm{~mm})$ these structures were well developed (see Fig. 8a, e).

The mature males with long antennules $(53 \%$ of body length) (Fig. 8a), having distally small, curved 


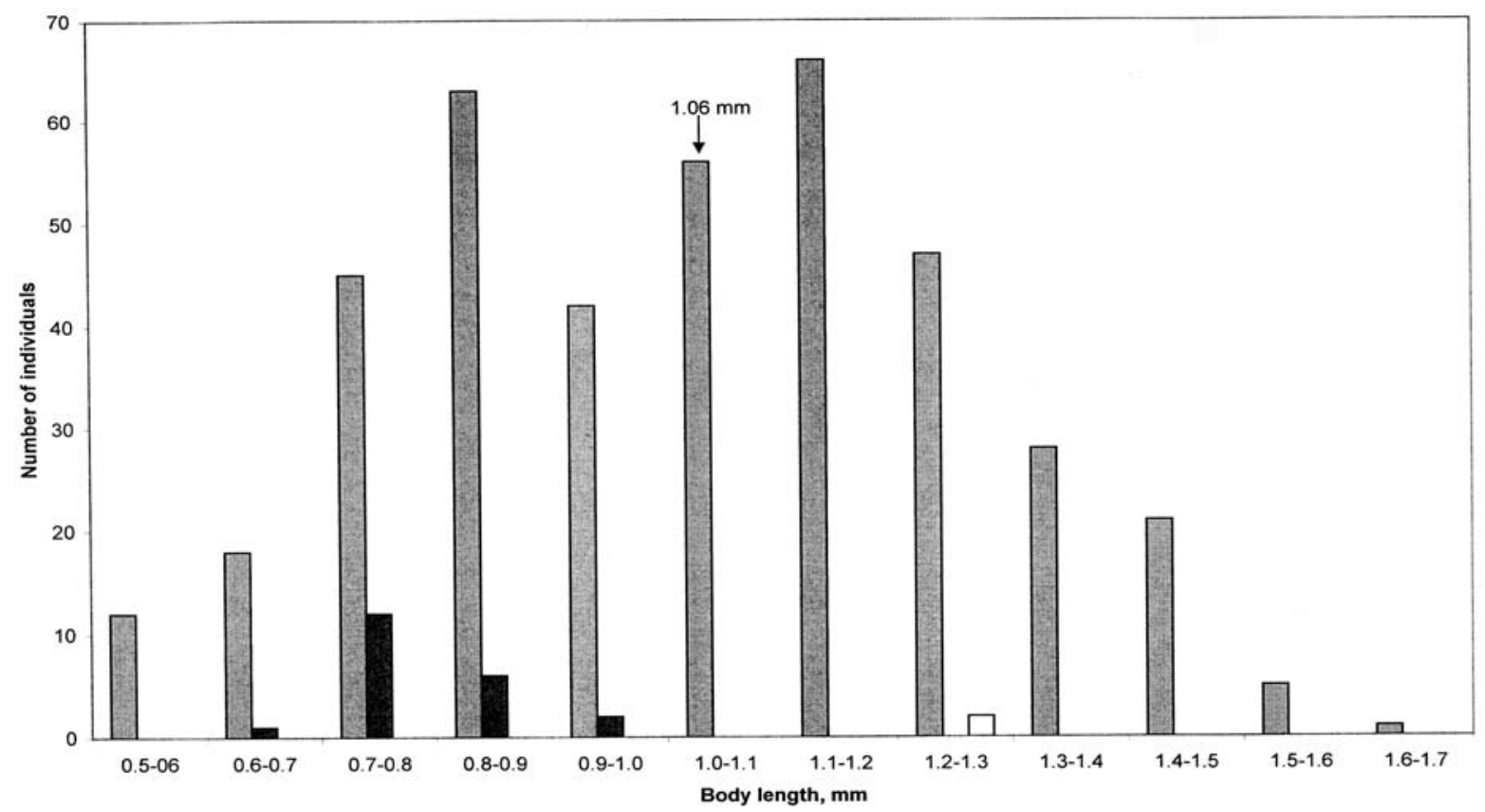

Fig. 7. Size-frequency structure of Diaphanosoma senegal isanensis specimens (sample 327) (arrow indicates body size of smallest female with parthenogenetic eggs in brood pouch): Columns: grey — juvenile and adult parthenogenetic females, black — males, white gamogenetic females.

Рис. 7. Размерно-возрастная структура особей Diaphanosoma senegal isanensis (проба 327): (стрелка указывает размер тела самки наименьшего размера с партеногенетическими яйцами в выводковой камере). Колонки: серые - ювенильные и взрослые партеногенетические самки, черные - самцы, белые - гамогенетические самки.

densely situated setules (Fig. 8b-c). Distal end of antennal basipodite with a large sharp thorn on its outer side (Fig. 8d). Hook on the end of endopodite of thoracic limbs of first pair massive, with small spinules on its concave side (Fig. 8f). A long non-plumose seta with broad base near this hook. Copulatory appendages long, tubular, somewhat broadening in their distal half (Fig. 8e).

Thus, the male specimens of D. s. isanensis do not differ from those found earlier in India and Bangladesh [see Korovchinsky, 1993]. Their diagnostic subspecies features coincide with those of females.

\section{Discussion}

The present investigation of Cladocera of Northern and Western Thailand is complementary regarding that one provided for Northeastern and Eastern Thailand [see Korovchinsky \& Sanoamuang, 2008a] which allows comparisons to be made more precisely.

The taxonomic composition at generic and higher taxa levels of faunas in both regions are similar. The representatives of the family Sididae always predominate followed by Daphniidae and Moinidae. All other taxa were more sporadic or rare, especially those of large Branchiopoda. Generally, the encountered characters of taxa frequency distribution, further confirms the previously outlined specificities of tropical zooplankton: predominance of few common eurytopic species of the genera Diaphanosoma, Moina, Ceriodaph- nia, Bosminopsis and rarity of Daphnia and Bosmina [see Fernando, 1980a, b].

The taxonomic composition of the family Sididae in Northern and Western Thailand is generally similar to that of Northeastern and Eastern Thailand, consisting of eight species (D. excisum, D. sarsi, D. volzi, $D$. dubium, D. senegal, D. elongatum, Latonopsis australis, Pseudosida szalayi). At the same time, two species known in the latter regions (Sida crystallina s.l. (O.F. Müller) and D. macrophthalma Korovchinsky et Mirabdullaev) lacking from the list. This is probably due to the isolation of Northern and Western Thailand from the influence of large rivers flowing from the north, mainly the Mekong River, and promoting distribution of the latter two species and other subtropical-temperate forms to the south throughout their basin. On the other hand, the frequent occurrence of mostly subtropical-temperate $D$. dubium in these northern and western regions of Thailand is even higher than in the north-eastern and eastern regions of the country and therefore seems to be not connected with the river's influence. Possibly the local success of the species is promoted by the higher elevation and milder climate of the area because its high abundance was also observed in the mountainous northern Vietnam [see Korovchinsky, 2000].

Further, the absolute dominance of D. excisum, which is frequently present as the only representative of Cladocera in local water bodies or as the only representative of planktonic cladocerans, was also recorded 


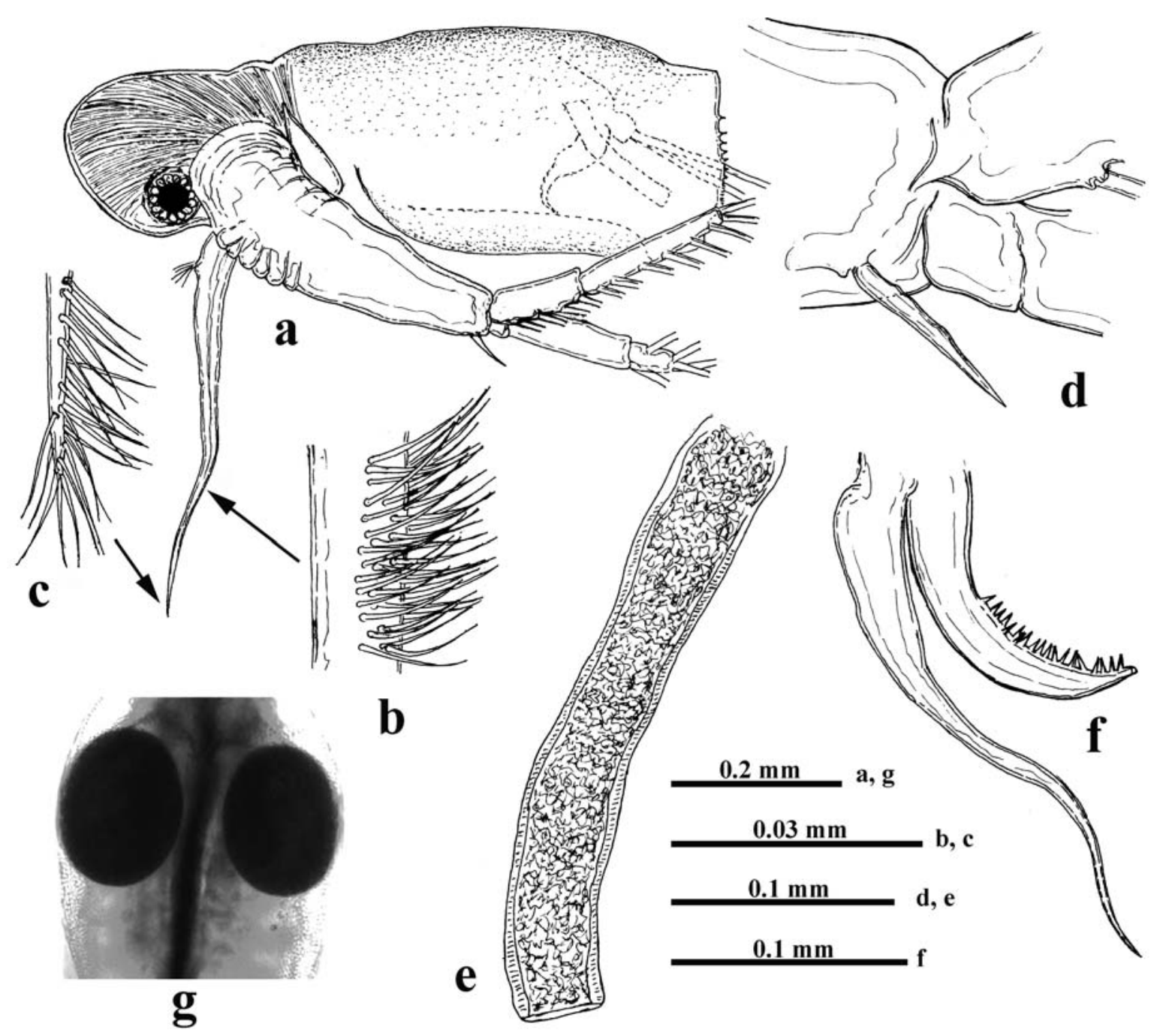

Fig. 8. Diaphanosoma senegal isanensis, male (sample 327): a - general lateral view, b, c - setules of different parts of antennule, $\mathrm{d}$ - large thorn of basipodital distal outer end, $\mathrm{e}$ - copulatory appendage, $\mathrm{f}$ - hook of thoracic limb of first pair, $\mathrm{g}$ - resting eggs in female's brood pouch.

Рис. 8. Diaphanosoma senegal isanensis, самец (проба 327): a - общий вид сбоку, b, c - сетулы разных частей антеннулы, d крупный шип внешней стороны дистального конца базиподита, е - копулятивный придаток, $\mathrm{f}$ - крючок торакальной конечности первой пары, g - стойкие яйца в выводковой камере самки.

in the waters of Northern and Western Thailand. $D$. volzi, D. senegal isanensis and D. elongatum were also rare (the latter species was found only in a single locality) though the former one seemed more frequent, being found in six localities in the Northern Thailand vs only one locality in the Northeastern Thailand [see Korovchinsky \& Sanoamuang, 2008a, b]. At the same time, the frequency of occurrence of D. sarsi, L. australis and $P$. szalayi was conspicuously lower in the former region.

The representatives of Sarsilatona were fragmentarily known only from the south of the country [Maiphae et al., 2008; Korovchinsky, Sanoamuang, 2008a], having not been found in the regions under consideration. Recently, these cladocerans were found in neighboring countries, Cambodia and in the south of
Vietnam [Tanaka and Ohtaka, 2010; Korovchinsky, 2011], where they inhabit small semi permanent ponds. Whether the absence of rare Sarsilatona from samples in Northeastern and Northern Thailand is caused by the southern limit of its range in Southeast Asia or simply by a lack of their habitats needs to be elucidated further.

Thus, it may be concluded that the species richness of Sididae in Northern and Western Thailand is comparatively impoverished which has also been seen from the recording of less numerous multispecies assemblages of the group (12 instead of 43 in the Northeastern Thailand) represented by a lower number of species (up to four co-occurring species of Sididae and up to three species of Diaphanosoma instead of five and four species, respectively, in Northeastern Thailand). 


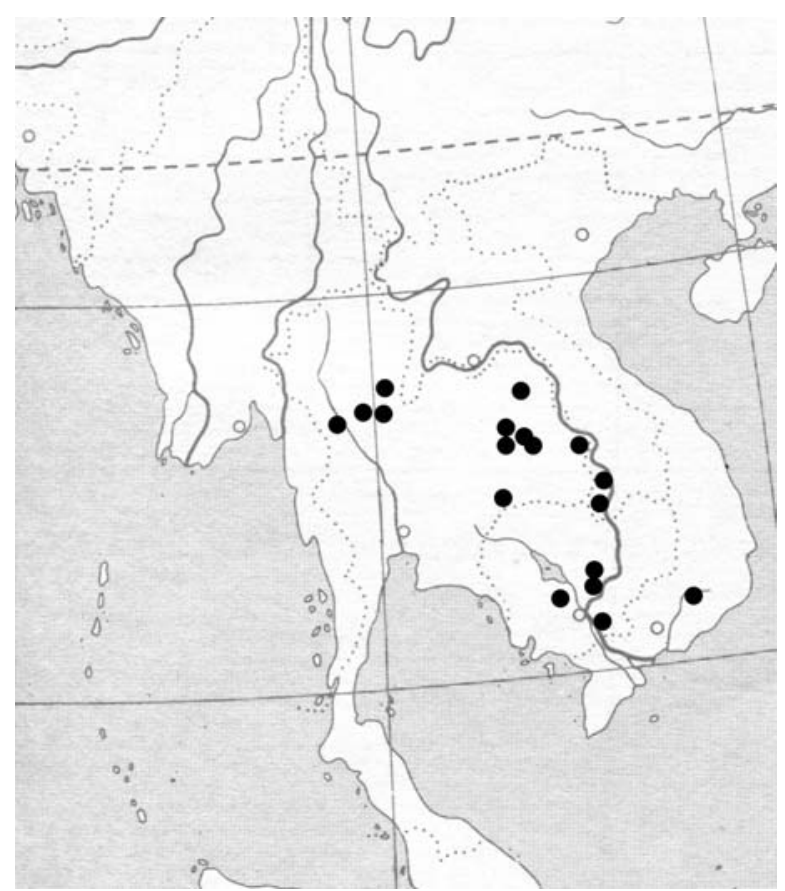

Fig. 9. The known localities of Diaphanosoma senegal isanensis in Southeast Asia.

Рис. 9. Известные местонахождения Diaphanosoma senegal isanensis в Юго-Восточной Азии.

This impoverishment may be explained by the general environmental characteristics of the region - considerable elevation above sea level and its isolation from the influence of large rivers flowing from the north and readily promoting the migration of northern faunal elements to the south.

In Northeastern Thailand D. senegal isanensis was found in seven localities and in Northern Thailand in four localities. Recently, unpublished records of the species have also been made in the neighboring countries - southernmost Laos [Ponthalith, 2006: two localities] and Cambodia [Mahasap, 2010: four localities]. In seven of 18 known localities (Fig. 9) this subspecies was found co-occurring with Anostraca and rarely with other large Branchiopoda. This data further confirms the tendency of $D$. senegal to form relict faunal complexes together with other rare primitive branchiopods. On the other hand, D. s. isanensis was found co-occurring with other common crustacean species, carnivore insects and fish fingerlings, which suggest again that these cladocerans can withstand competition and can survive under fish predation pressure [see Korovchinsky, 1993].

ACKNOWLEDGMENTS. This work was supported by the Higher Education Research Promotion and National Research University Project of Thailand, Office of the Higher Education Commission, through the Holistic Watershed Management Cluster of Khon Kaen University. NMK thanks Drs. Khunapat Proongkiat, Sujiporn Athibai, Wipavee Dararat, Suttana Plodsomboon and students of the Applied Taxonomic Research Center for help during his stay in Thailand. Professor N.N. Smirnov and Dr. A.A. Kotov (Institute of
Ecology and Evolution, Moscow, Russia) are much thanked for valuable discussion and text correction and Dr. J. Dodgson for their help with the English correction.

\section{References}

Fernando C.H. 1980a. The species and size composition of tropical freshwater zooplankton with special reference to the Oriental region (Southeast Asia) // Int. Rev. ges. Hydrobiol. Vol.65. P.411-426.

Fernando C.H. 1980b. The freshwater zooplankton of Sri Lanka, with a discussion of tropical freshwater zooplankton composition // Int. Rev. ges. Hydrobiol. Vol.65. P.85-125.

Korovchinsky N.M. 1993. Description of the male, analysis of morphological variability and geographical distribution of $\mathrm{Di}$ aphanosoma senegal Gauthier, 1951// Hydrobiologia. Vol.259. P.9-16.

Korovchinsky N.M. 2000. Redescription of Diaphanosoma dubium Manuilova, 1964 (Branchiopoda: Ctenopoda: Sididae), and description of a new, related species // Hydrobiologia. Vol.441. P.73-92.

Korovchinsky N.M. 2010. A taxonomic revision of Pseudosida szalayi Daday, 1898 (Crustacea: Cladocera: Sididae) over its Asian range, with focus on the northernmost populations first recorded from the Amur River basin (Far East of Russia) // Zootaxa. Vol.2345. P.1-18.

Korovchinsky N.M. 2011. Description of Sarsilatona cf. fernandoi (Rane, 1983) (Crustacea: Cladocera: Sididae) found in the south of Vietnam // Zootaxa. Vol.3129. P.29-38.

Korovchinsky N.M., Sanoamuang L. 2008a. Overview of Sididae (Crustacea: Cladocera: Ctenopoda) of Northeast and East Thailand, with description of a new species of the genus Diaphanosoma // Zootaxa. Vol.1682. P.45-61.

Korovchinsky N.M., Sanoamuang L. 2008b. Diaphanosoma senegal Gauthier, 1951 (Crustacea: Cladocera: Sididae) in SouthEast Asia // Zootaxa. Vol.1695. P.53-60.

Kotov A.A., Sanoamuang L. 2004. Ilyocryptus thailandensis sp. nov. (Cladocera: Anomopoda: Ilyocryptidae) from North Thailand // Int. Rev. Hydrobiol. Vol.89. P.206-214.

Mahasap W. 2010. Species diversity and distribution of cladocerans in 5 provinces in central, eastern, and southern parts of Cambodia. M.Sc. Thesis. Khon Kaen University. 103 pp.

Maiphae S., Pholpuntin P., Dumont H.J. 2005. Species richness of the Cladocera (Branchiopoda: Anomopoda and Ctenopoda) in southern Thailand, and its complementarity with neighboring regions // Hydrobiologia. Vol.537. P.147-156.

Maiphae S., Pholpuntin P., Dumont H.J. 2008. Taxon richness and biogeography of the Cladocera (Crustacea: Ctenopoda, Anomopoda) of Thailand // Ann. Limnol. - Int. J. Limnol. No.1. P. 31-41.

Ponthalith C. 2006. Species diversity and distribution of Cladocera in Champasak Province, Lao PDR. M.Sc. Thesis. Khon Kaen University. $73 \mathrm{pp}$.

Sa-ardrit P. 2002. Diversity and distribution of freshwater Cladocera in Trang Province. M.Sc. Thesis. Prince of Songkla University. 98 pp.

Sa-ardrit P., Beamish F.W.H. 2005. Cladocera diversity, abundance and habitat in a Western Thailand stream // Aquat. Ecol. Vol.39. P.353-365.

Saeng-aroon C., Sanoamuang L. 2002. Species diversity and abundance of Cladocera in Lake Kud-Thing, Nong Khai Province // KKU Res. J. Vol.7. P.14-25.

Sanoamuang L. 1998. Contributions to the knowledge of the Cladocera of north-east Thailand // Hydrobiologia. Vol.362. P.45-53.

Sanoamuang L., Faitakum S. 2005. Species diversity of cladocerans and copepods in the floodplain of the River Mun, Northeast Thailand // KKU Res. J. Vol.10. P.106-113.

Tanaka S., Ohtaka A. 2010. Freshwater Cladocera (Crustacea, Branchiopoda) in Lake Tonle Sap and its adjacent waters in Cambodia // Limnology. Vol.11. P.171-178.

Responsible editor V.N. Ivanenko 